\title{
The factors of family business successor readiness and how their impact on the business transition from succes- sors' perspectives
}

\author{
Nattapat Chanchotiyan ${ }^{1 *}$, Kavin Asavanant ${ }^{2}$ \\ ${ }^{1}$ Technopreneurship and Innovation Management Program, Graduate School, Chulalongkorn University, \\ Bangkok, Thailand \\ ${ }^{2}$ Chulalongkorn Business School, Chulalongkorn University, Bangkok, Thailand
}

\section{Keywords \\ Family business \\ Succession \\ Successor \\ Readiness \\ Management}

Received: 14 May 2020

Accepted: 23 July 2020

Published: 20 October 2020

\begin{abstract}
This paper aimed to 1) study the factors of family business successor readiness and 2) investigate the obstacles that are mostly found during the succession process and factors that lead to successful succession in family business from successors' perspectives. The study was undertaken in Thailand among eight family business successors who ran medium to large-size family businesses based on qualitative research. They already had a successful transition in their family businesses. The participants were selected by purposive sampling technique; including family business successors from pharmaceutical industry, tea industry, packaging industry, energy industry, food processing industry, and shoe industry. The findings revealed that nine factors contribute to the successor's readiness: 1) working experience in the family company, 2) working experience in other company, 3) industry-specific knowledge, 4) reward or cash compensation, 5) personal interests or needs, 6) commitment to the company, 7) relationship among family members, 8) family harmony, and 9) trust in successor's ability. By addressing these nine factors appropriately from both the predecessors and successors, the family business will ensure its continuity into the future.
\end{abstract}

(C) 2020 The Author(s). Published by TAF Publishing.

\section{INTRODUCTION}

About 50-90 percent of Gross Domestic Product in global economy are generated by family businesses (Kenyon-Rouvinez \& Ward, 2005). Though, only 13 percent of family businesses survive through third generation (Ward, 1997/2011). Family business succession is a key to reduce the failure rate and leads to sustainable business. For those family businesses who want to survive, they plan and manage succession appropriately (Aronoff, McClure, \& Ward, 1991/2011; Mokhber et al., 2017). According to 2019 Global Family Business Survey by The Step Project (2019), 70\% of family business leaders do not have succession plan which reflects business transition problems and explains why most family businesses struggle and fail. Apart from well planning and managing (Aronoff et al.,
1991/2011), the succession process also requires good cooperation among family members, especially successors. Successors are considered as the most important people during the process, because they will take control of family businesses in the future. Thus, it is necessary to appropriately select successors and prepare them before going into the process. Successors should have skills and abilities in various fields, for example management skills (Ibrahim, Soufani, Poutziouris, \& Lam, 2004; Ward, 1997/2011), leadership skills (Ibrahim et al., 2004), understanding in business areas (Mokhber et al., 2017; Venter, Boshoff, \& Maas, 2005; Ward, 1997/2011), understanding in family business (Venter et al., 2005), etc. Recent literatures have identified many factors that lead to successful succession in family business and most of them are related to successors. Nev-

* corresponding author: Nattapat Chanchotiyan

†email: nattapat.chanchotiyan@gmail.com 
ertheless, limited literatures focus on learning something from successors' perspectives.

\section{Family Business Issues}

Most of family businesses cannot last through third generation. From the first generation to the second generation, survival rates are less than two thirds. In the third generation, there would be 13 percent of the businesses that survive, and only three percent of the businesses would survive through fourth generation (Aronoff et al., 1991/2011; Ward, 1997/2011). As far as low survival rate is concerned, there are issues that family businesses face which can be categorized into two groups: family-related issues and business-related issues.

\section{Family-Related Issues}

As family businesses mainly operate by family members, people who work in the business are from different generations. Thus, family business can be considered as multigeneration workplace which face challenges from the difference of personal goals, personalities, and expectations (Kpmg International, 2011). If they are not open-minded and do not trust each other, there will be nepotism and disagreement over rewards and compensations which cause conflict in the businesses. Moreover, people in different generations or even same generations often compete with each other for getting something better than another (Schwass \& Glemser, 2016; Ward, 1997/2011). Thus, many families that know about these issues do not take much effort to persuade their family members to work in companies if they are not willing to do (Ward, 1997/2011). As mentioned above, according to 2019 Global Family Business Survey by The Step Project (2019), 70\% of family business leaders do not have succession plan. Even the qualifications or skills that successors should have or prepare to develop, family business leaders also leave it to successors and let successors guess on their own (Schlepphorst \& Moog, 2014). If the leaders suddenly die, the businesses will need to continuously run without the leaders and the successor selection process will be set up urgently, which means no one will be ready for it (Ward, 1997/2011). For those who are not ready, they will likely do not have the same level of business competency as the former leaders (Schwass, 2005).

\section{Business-Related Issues}

Family businesses are like other companies that need to focus on business performance and profit. With unique characteristics, family businesses face with a lot of challenges related to the business. Many family businesses do not have appropriate business policies, especially employment (Kpmg International, 2011). Family businesses, especially small-size businesses, often pay under market rate (Kenyon-Rouvinez \& Ward, 2005). As a result, lack of experts and professionals is usual situation that we can find in family business areas. Some family businesses that have high personal financial needs in their families and do not have financial management experts tend to slowly grow, as they often spend business money with their own needs and lose the opportunities to invest in their businesses. Family business leaders tend to run the businesses as they are. They rarely plan for the future and do not take seriously on sourcing modern tools that can help them easily deal with challenges (Ward, 1997/2011).

\section{FACTORS FOR SUCCESSFUL SUCCESSION IN FAMILY BUSINESS}

To reduce the failure of family business, leaders should consider the succession. Since the succession is not an easy task to achieve, family business leaders need to plan and manage succession appropriately (Aronoff et al., 1991/2011; Ward, 1997/2011). To help the leaders effectively plan, there are various factors that lead to successful succession in family business which can be categorized into three groups: family-related factors, business-related factors and succession context-related factors.

\section{Family-Related Factors}

As mentioned, family business succession requires good cooperation among family members. Thus, the factors that are related to family relationship are extremely important. Relationship between family members and family harmony should be considered first. Family leaders need to resolve conflicts in family before entering the succession process (Ward, 1997/2011). Family businesses should strengthen the relationship between family members by talking and sharing ideas on any topics (Venter, Boshoff, \& Maas, 2003) and giving respect to each other (Ibrahim et al., 2004). Relationship between predecessors and successors is also important. Predecessors should be open-minded, trust in successor's abilities and give them the opportunities for making decisions (Venter et al., 2005). It is quite necessary for predecessors to communicate their willing to have successors in the businesses (Ward, 1997/2011). Good relationship between predecessors and successors will encourage both predecessors and successors to share their knowledge throughout the process (Alayo, Iturralde, Maseda, \& Arzubiaga, 2016; Venter et al., 2005; Ziniel \& Voithofer, 2016). Moreover, family business should consider about successor 
willingness to take over business. The motivation should be offered to successors in some way. For example attractive compensation (Aronoff, McClure, \& Ward, 1993/2011), enjoyable work (Venter et al., 2005) which could be consider as an alignment of personal interests or needs (Ward, $1997 / 2011$ ) and commitment to the company (Chrisman, Chua, \& Sharma, 1998; Ibrahim et al., 2004; Sharma \& Srinivas Rao, 2000; Wang, Lo, \& Weng, 2019). Besides those mentioned above, successors preparation also needs to be mentioned. Developing skills and abilities of successors by giving appropriate education, work experience in both family businesses and other companies, industry specific knowledge (Mokhber et al., 2017; Venter et al., 2005; Ward, $1997 / 2011$ ) and understanding of family business (Ward, 1997/2011).

\section{Business-Related Factors}

Family businesses need to have good corporate governance. Leaders should care about benefit of stakeholders and manage it properly. The structure of business also needs to re-organize. Some family businesses may consider to set up family council to control business management transparency (Venter et al., 2003; Ward, 1997/2011). For those family businesses that do not have appropriate business policies, all should develop strategies and create formal management systems to get ready for changes (Ward, 1997/2011).

\section{Succession Context-Related Factors}

Regarding succession process, the context surrounds it should not be ignored. The quality of successors is critical, as they will lead the business in the future. Successors should have skills and abilities in various fields (Alayo et al., 2016; Mokhber et al., 2017), for example management skills (Ibrahim et al., 2004; Ward, 1997/2011), leadership skills (Ibrahim et al., 2004), understanding in business areas (Mokhber et al., 2017; Venter et al., 2005; Ward, $1997 / 2011$ ), understanding in family business (Venter et al., 2005), etc.

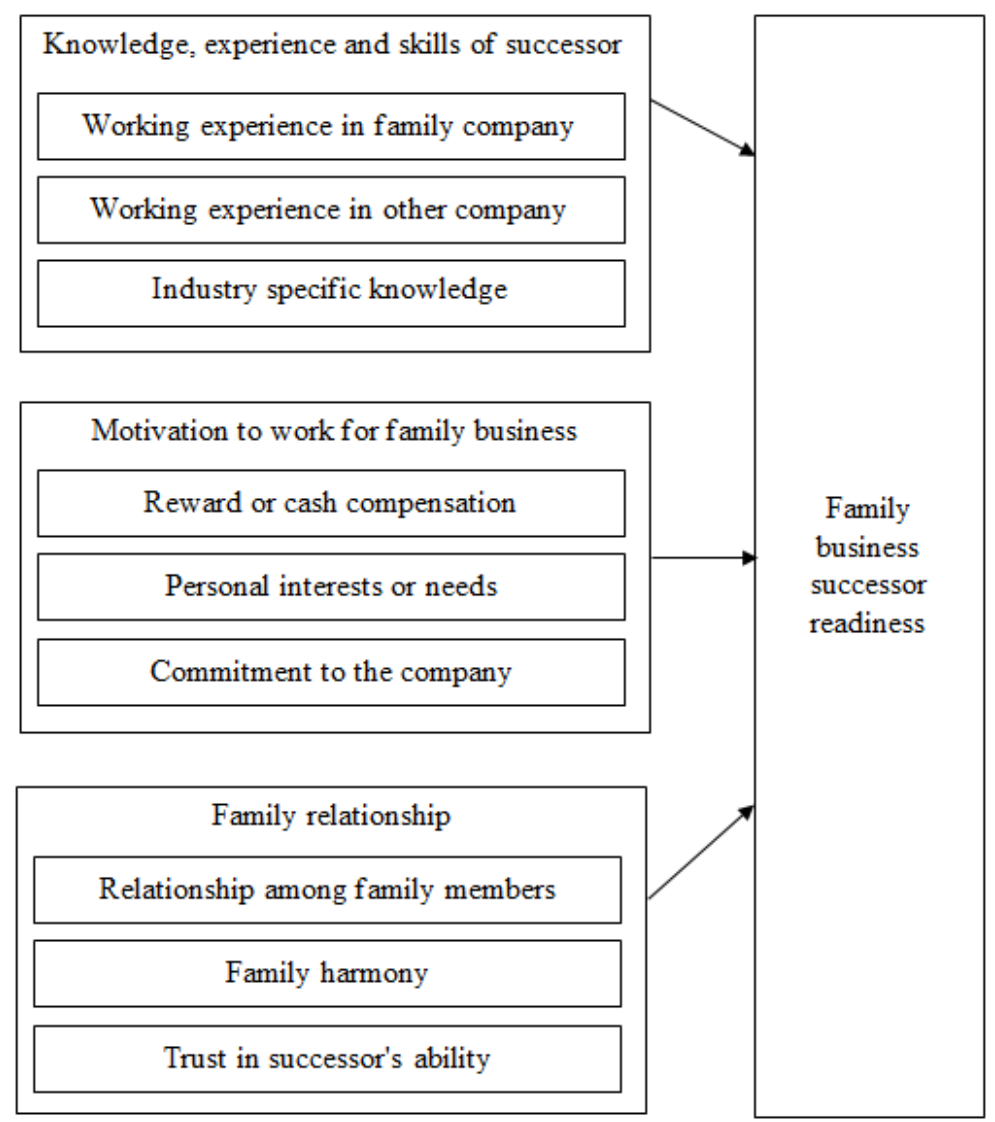

FIGURE 1. Conceptual framework 
These skills and abilities could be developed through gaining experience in and out family business and learning specific knowledge of family business (Venter et al., 2005; Ward, 1997/2011). Besides the quality of successors, succession process should be written in detail; including procedure and timeline. All related parties of succession process need to agree and accept that written plan (Venter et al., 2003; Ward, 1997/2011).

According to above factors, we found that most of them were related to successor one way or the other. We selected some of them and developed conceptual framework (see Figure 1) to study the factors of family business successor readiness.

\section{RESEARCH METHODOLOGY}

After developing conceptual framework, we conducted qualitative research with Thai family business successors to deeply understand family business successor readiness factors, the obstacles that are mostly found during the succession process and successful succession factors from successors' perspectives.

\section{Sample}

We applied purposive sampling technique to select participants, using our judgment based on participant information (Berg, 2001). We focused on family business successors who ran medium to large-size family businesses in Thailand and already had a successful transition in their family businesses. Based on the judgment, we selected eight successors from six industries; including pharmaceutical industry, tea industry, packaging industry, energy industry, food processing industry, and shoe industry. They are all in 2nd and 3rd generation of their companies (See Table 1).

TABLE 1. Participant information

\begin{tabular}{lll}
\hline \hline Industry & Generation & No. Participants \\
\hline Pharmaceutical & 3 & 3 \\
Tea & 3 & 1 \\
Packaging & 2 & 1 \\
Energy & 2 & 1 \\
Food processing & 2 & 1 \\
Shoe & 3 & 1 \\
\hline \hline
\end{tabular}

\section{Gathering and Analyzing the Data}

We conducted interviews with selected participants. The interviews were carried out using an interview guide with four main topics:

1) Knowledge and Experience topics: working experience in family company, working experience in other company, and industry specific knowledge.
2) Motivation to work for family business topics: reward or cash compensation, personal interests or needs, and commitment to the company.

3) Family relationship topics: relationship among family members, family harmony, and trust in successor's ability.

4) Obstacles in succession process and way to successful succession.

With participants' permission, conversations during the interview were recorded and transcribed. After that we sought the similarities and differences of each word in the data and coded them with representative words or phrases. Then we identified meaningful patterns and analyzed them with previous researches (Berg, 2001).

\section{FINDINGS}

Based on the qualitative research, all nine factors in conceptual framework (see Figure 1) had positive effect on family business successor readiness. The detail of each factor could be described as follows.

\section{Knowledge, Experience and Skills of Successor Working experience in family company}

The findings revealed that successors would be ready for the succession if they had involved and had been trained to work in family business since they were young. Gaining experience in family company would help them truly understand family business and gradually groomed them to be confident enough to take care of business in the future.

\section{Working experience in other company}

According to the research, working experience in other companies would give successors opportunities to learn standard business practices, especially from operational level. This experience could help them understand their employees once they took care of the family business. Moreover, if the experience was relevant to family business, they would be more ready for the succession.

\section{Industry specific knowledge}

It appeared that successors who ever attended seminars or training classes that related to family business would be ready for the succession. Thus, to enhance industry specific knowledge was not just to encourage successors to learn something. But it was necessary to select seminars or training classes that were relevant to family business which could be applied to their family business management. 


\section{Motivation to Work for Family Business Reward or cash compensation}

Successors would be ready for the succession if they got satisfied reward or cash compensation offerings. The appropriateness of the offerings was various, depending on attitude towards money of each successor. If successors did not focus on money, it was not necessary to offer them much money. However, for those who think that money was important, the offerings must be carefully considered to be better or at least the same level compared to other companies.

\section{Personal interests or needs}

Research results revealed that family business involvement since childhood would help successors be familiar with family businesses and get ready for the succession. Being told about the business history and the hardships faced by past generations would help successors perceive the value of family business and would like to involve in the business. Moreover, being taught the value of money and the important of doing business since they were young could increase their readiness. As far as influence on career path decision was concerned, the findings showed that if successors were independent and had their own hobbies, explaining the advantages of doing family businesses that could help them easily work on hobbies would be proper way to do. Nevertheless, if the successors were obedient and potential, direct influence could be considered.

\section{Commitment to the company}

The results showed that family business involvement since childhood, being told about the business history and the hardships faced by past generations were not only related to personal interests or needs factor, but also related to commitment to the company. Explaining great contributions of family businesses for nourishing their families was important. Additionally, family activities should be implemented to create love and commitment within families. These actions would help successors be ready for the succession.

\section{Family Relationship}

\section{Relationship among family members}

The finding revealed that successors would be ready for the succession if their families properly managed their own relationship. The results suggested that family businesses should have family activities to build good relationship among family members. Establishing family councils would help family business manage their own relationship effectively. In addition, conflict management should be considered as a required subject for all successors which it would help successors easily manage the problems and see it as challenging tasks to achieve.

\section{Family harmony}

It appeared that successors would be ready for the succession if there were clear roles and responsibilities in the family businesses which family members separately worked in the company and did not need to discuss on any issues with each other. Moreover, if successors could handle conflict in the business, they would be ready for the succession as well. Regarding conflict management, the results suggested that successors could follow this guide:

1) Keep calm

2) Choose appropriate way to speak with others

3) Find coalitions in the company

\section{Trust in successor's ability}

According to the research, trust in successor's ability expression was important to get successors ready for the succession. There were various ways to express trust in successor's ability, for example giving special project assignments, letting they work on their own, sincerely giving the compliment on their work.

Apart from readiness factors, the findings also revealed the obstacles that were mostly found during the succession process and successful succession factors from successors' perspectives as follows.

\section{Succession Obstacles}

The results showed that there were three main obstacles which were found during the succession process. All three main obstacles could be described as follows.

\section{Difficulty in working with employees}

Successors often faced with employees who did not follow their orders, gave them incorrect information about the work, and were dissatisfied with successors. The results suggested that successors should get acquainted with employees and express their cares sincerely. They should show their abilities, so employees would trust them. Additionally, successors could consult predecessors or well-experienced people.

\section{Management}

Successors who just involved in succession process might have less experience in management. Thus, they often had difficulty in management both people management and work management. The results suggested that successors should learn to manage people by working in the business, studying people management. Regarding work manage- 
ment, successors should keep calm and solve the problems one by one. Nevertheless, successors could consult predecessors or well-experienced people as well.

\section{Workplace conflicts}

This problem directly caused by conflicts in family. The results suggested that management team should set clear roles and responsibilities in the family businesses which family members separately worked in the company. For those who could not manage by themselves, all might need to hire family business consultants to professionally manage organization.

\section{Successful Succession Factors}

According to the research, there were three factors which could help succession process succeeded. All three factors could be described as follows.

\section{Successors' interests, commitment, and ambition to work in family businesses}

Telling the business history, the hardships faced by past generations, family values, and family business involvement since childhood could generate this factor.

\section{Successors' opportunities to work on their own}

As mentioned above, trust in successor's ability was important. This factor confirmed that statement. Successors should have the opportunities to work on special projects on their own. It would train them to be professional manager and truly understand their family businesses.

\section{Successors' working experience in other companies}

Gaining experience outside family businesses would give successors valuable opportunities to learn from professionals. Successors would see effective working system which could be applied to family business. Furthermore, they would get to know with someone who could become partners with their family businesses.

\section{DISCUSSION AND CONCLUSION}

In this paper, we studied the factors of family business successor readiness and investigate the obstacles that are mostly found during the succession process and factors that lead to successful succession in family business from successors' perspectives by using qualitative study with eight family business successors who ran medium to large-size family businesses in Thailand and already had a successful transition in their family businesses. Based on the findings, there were nine factors that had positive effect on the successor's readiness.

In terms of the knowledge, experience and skills of suc- cessor group of factors, consisting of working experience in family company, working experience in other company, and industry specific knowledge, all factors were compatible with Ward (1997/2011) who suggested that successors could develop skills and abilities through gaining experience in and out family business and learning specific knowledge of family business.

As for motivation to work for family business group of factors, consisting of reward or cash compensation, personal interests or needs, and commitment to the company, we found interesting findings about reward or cash compensation which enhanced the findings of Aronoff et al. (1993/2011) who pointed out that it was important to offer attractive compensation to successors. The study revealed that successors should get satisfied reward or cash compensation that aligned with their attitude towards money. If successors did not focus on money, offering large amounts of money would not help them to be ready for the succession. Other motivation related to intrinsic motivation should be considered. Personal interests or needs and commitment to the company were reconcilable with Venter et al. (2005) who reported that successors should be happy with family businesses. They also had better see family businesses as an enjoyable work. Moreover, Chrisman et al. (1998) mentioned that commitment to business was really important attributes of successors.

Regarding family relationship group of factors, consisting of relationship among family members, family harmony, and trust in successor's ability, all factors were compatible with previous researchers' findings. For instance, Ward (1997/2011) suggested that family leaders should resolve conflicts in family before entering the succession process. Venter et al. (2003) reported that family businesses should strengthen the relationship between family members by talking and sharing ideas on any topics. In addition, Ward (1997/2011) pointed out that predecessors should communicate their willing to have successors in the businesses. Apart from factors of family business successor readiness, we also found three main obstacles that are mostly found during the succession process and three factors that lead to successful succession in family business which were all compatible with previous researchers' findings. For example, workplace conflicts which we considered as an obstacle that directly caused by conflicts in family was compatible with the report of Kpmg International (2011) who presented that family businesses could be considered as multigeneration workplace which face challenges from the difference of personal goals, personalities, and expectations. As for successful succession factors, we found that successors 
should have the opportunities to work on special projects on their own. This result was reconcilable with Venter et al. (2005) who addressed that predecessors should be openminded, trust in successor's abilities and give them the opportunities for making decisions.

\section{LIMITATIONS AND FUTURE RESEARCH}

This paper was an interview-based study. We conducted the interviews with only family business successors. Further study could be extended to predecessors to get data in another aspect and make the study results more credible. Since this study collected data from six industries, the results would be quite general. Further study could work on the sample group in a particular industry to generate more specific information which could be appropriately adapted with each industry. Moreover, this study selected group of successors range from 2nd and 3rd generation. Further study could focus on a particular generation to obtain specific information from each generation which would bring more applicable results.

\section{REFERENCES}

Alayo, M., Iturralde, T., Maseda, A., \& Arzubiaga, U. (2016). Critical factors for successful succession of family firms. European Journal of Economics, Finance and Administrative Sciences, 85(6), 90-103.

Aronoff, C. E., McClure, S. L., \& Ward, J. L. (1991/2011). Family business succession. London, UK: Palgrave Macmillan. (Original work published 1991) doi:https://doi.org/10.1007/978-1-137-51208-6

Aronoff, C. E., McClure, S. L., \& Ward, J. L. (1993/2011). Family business compensation. London, UK: Palgrave Macmillan. (Original work published 1993) doi:https://doi.org/10.1057/9780230116009

Berg, B. (2001). Qualitative research methods for the social sciences. Massachusetts, MA: Pearson.

Chrisman, J. J., Chua, J. H., \& Sharma, P. (1998). Important attributes of successors in family business: An exploratory study. Family Business Review, 11(1), 19-34. doi:https://doi.org/10.1111/j.1741-6248.1998.00019.x

Ibrahim, A., Soufani, K., Poutziouris, P., \& Lam, J. (2004). Qualities of an effective successor: The role of education and training. Education and Training, 46(8), 474-480. doi:https://doi.org/10.1108/00400910410569597

Kenyon-Rouvinez, D., \& Ward, J. L. (2005). Family business. London, UK: Palgrave Macmillan. doi:https://doi.org/10.1057/ 9780230287730

Kpmg International. (2011). Family business succession managing the all-important family component. Retrieved from https://bit.1y/30NcyRI

Mokhber, M., Gi, T. G., Rasid, S. Z. A., Vakilbashi, A., Zamil, N. M., \& Seng, Y. W. (2017). Succession planning and family business performance in SMEs. Journal of Management Development, 36(3), 330-347. doi:https://doi.org/10.1108/ JMD-12-2015-0171

Schlepphorst, S., \& Moog, P. (2014). Left in the dark: Family successors' requirement profiles in the family business succession process. Journal of Family Business Strategy, 5(4), 358-371. doi:https://doi.org/10.1016/j.jfbs.2014.08.004

Schwass, J. (2005). Wise growth strategies in leading family businesses. London, UK: Palgrave Macmillan. doi:https:// doi.org/10.1057/9780230513358

Schwass, J., \& Glemser, A.-C. (2016). Wise family business. London, UK: Palgrave Macmillan. doi:https://doi.org/10.1057/ 978-1-137-58600-1

Sharma, P., \& Srinivas Rao, A. (2000). Successor attributes in Indian and Canadian family firms: A comparative study. Family Business Review, 13(4), 313-330. doi:https://doi.org/10.1111/j.1741-6248.2000.00313.x

The Step Project. (2019). 2019 global family business survey: The impact of changing demographics on family business succession planning and governance. Retrieved from https://bit.ly/3jfXdPH

Venter, E., Boshoff, C., \& Maas, G. (2003). The influence of relational factors on successful succession in family businesses: A comparative study of owner-managers and successors. South African Journal of Business Management, 34(4), 1-14. doi:https://doi.org/10.4102/sajbm.v34i4.687

Venter, E., Boshoff, C., \& Maas, G. (2005). The influence of successor-related factors on the succession process in small and medium-sized family businesses. Family Business Review, 18(4), 283-303. doi:https://doi.org/10.1111/j.1741-6248 .2005.00049.x

Wang, Y.-Z., Lo, F.-Y., \& Weng, S.-M. (2019). Family businesses successors knowledge and willingness on sustainable innovation: The moderating role of leader's approval. Journal of Innovation \& Knowledge, 4(3), 188-195. doi:https://doi.org/ 10.1016/j.jik.2019.05.001 
Ward, J. L. (1997/2011). Keeping the family business healthy. London, UK: Palgrave Macmillan. (Original work Published 1997) doi:https://doi.org/10.1057/9780230116122

Ziniel, W., \& Voithofer, P. (2016). Family business succession in Austria satisfaction and the incumbent-successor relationship. Vezetéstudomány-Budapest Management Review, 47(11), 29-37. doi:https://doi.org/10.14267/VEZTUD.2016 .11 .04 